\title{
Elderly Anxiety in the Process of Regular Hajj
}

\author{
Farah Zahruna Thirafi \& Siti Nurina Hakim \\ Faculty of Psychology, University of Muhammadiyah Surakarta \\ farahzahruna@gmail.com,snh147@ums.ac.id; ayya_inna@yahoo,co.id
}

\begin{abstract}
Hajj is an annual worship performed by muslims throughout the world for those who are able to do it. The gathering of muslims all over the world in one place at the same time can be a concern for someone, especially for the elderly. In addition, various activities in the pilgrimage, worship site conditions that are not livable, and encountering various kinds of characters and human nature can also become burdens for the elderly. The purpose of this study is to identify the anxiety of elderly in the process of implementing a regular pilgrimage. The survey was conducted in two couples of elderly who run the hajj together, didn't have severe disease, and whose age more than 60 years, through a regular pilgrimage program. The informant retrieval method is by purposive sampling, while the retrieval of data used closed questionnaires and interviews covered with expert judgment to see the validity of the interview guide questions. The results of the study obtained that all subjects experienced anxiety, especially when mabit (stay overnight) in muzdalifah, mina and throw jumrah (stoning of the devil). The anxiety was caused by environmental factors, weather, physical and emotional state of the subjects. Perceiving and prayer are coping methods performed by the subjects to relieve their anxiety. Good spirit and strong intention of the subjects can also reduce their level of anxiety.
\end{abstract}

Keywords:Anxiety, elderly, regular hajj

\section{INTRODUCTION}

Hajj is the fifth pillar of Islam, after creed, prayer, charity and fasting. Hajj is an annual ritual performed by Muslims worldwide that is capable (in terms of wealth, health, and knowledge) to visit and carry out some activities in several places in Saudi Arabia at a time known as the Hajj season.

The process of hajj began on 8 Dzulhijjah when pilgrims go to Mina for mabit, then 9 Dzulhijjah when pilgrims stand at Arafat and mabit in Muzdalifah, followed on 10 Dzulhijjah when pilgrims throw jumrah, then the pilgrims can have first tahallul and be allowed to take off the ihram cloth and wearing fragrances. On 11 and 12 Dzulhijjah, pilgrims throw jumrah, then go to Mecca for thawaf and sa'i. On the 13 Dzulhijjah, pilgrims throw three jumrah then go to Mecca for the thawaf and sa'i.

During the Hajj, the pilgrims shall go to other places outside of Mecca, namely Arafah, Muzdalifah and Mina. Physically, the third place was not in Mecca. It is between 5 to $25 \mathrm{~km}$ out of the town. Outside the Hajj season, Mina is not a decent place to live or occupied by humans, because it consists of desert and rock only (Juwita, 2013).

The rough terrain to be pursued and the many activities of Hajj requires the pilgrims to fulfill certain conditions. When someone is physically healthy, has enough money for lunch and trip without burdening themselves, has no deterring disease, nor laziness or impeding enemy, has no weakness in walking or running, or provisions in general, then he is already the subject to liability of performing Hajj (Tausikal, 2014).
An elderly performing pilgrimage is also under greater pressure because he tends to rely on his family in his daily life. Meanwhile, when an elderly is performing Hajj, his dependence on his family will be transferred into his Hajj group. In such situation, the elderly will feel alienated and guilty because the group activities become obstructed (Suardiman, 2011). These feelings of being alienated and guilty would make the elderly more anxious, although a person basically is able to modify his beliefs by training his thinking ability.

In Hajj season, pilgrims are required to adapt to the new environment and extreme weather in a short period of around forty days, whereas the normal time needed to adapt is approximately 3 months, especially for elderly pilgrims who have difficulty adapting and declining health. Besides adapting to the weather, elderly pilgrims are also exposed to emotional adjustment, gathering of people from various countries with diverse habits and customs that will cause unfamiliar behaviors such as grabbing queues, unwillingness to give in, and shoving others, so it is important to foster prejudices and negative emotions in the elderly (Ramaiah, 2002).

Elderly is the last stage of a person's life cycle. When a person is getting older, they tend to be potentially experiencing health problems (Suyanta\&Ekowarni, 2012). Santrock (2012) adds that this stage begins at the age of 60 or 70 years until the time of death. This period is a time to review the life that has been learned, to pension, to adapt to the new social roles, and to experience decreased strength and health.

New environmental conditions and extreme weather cause the worshipers to feel anxious. Taylor explains that anxiety is a subjective experience of the mental tension as a general reaction because of the inability to face 
problems or insecurity, which will generally lead to physiological symptoms, such as shaking, sweating, increased heart rate, etc. and psychological symptoms, such as panic, tense, confused, unable to concentrate, and so on (Suardana\&Simarata, 2013).

Anxiety is also a fear of things that does not necessarily happen. Feelings of anxiety usually appear when we are in a situation that is expected to be adverse and threatening, because we feel powerless to deal with it (Djumhana, 2001).

The term anxiety is the result of psychological and physiological processes in human body. Anxiety is not the same with fear, because anxiety is a reaction to danger. Anxiety can appear alone or joined with other symptoms of emotional disorders due to environment, depression, and other physical causes. Anxiety is not a disease, but it is a sign that appears at a certain time (Ramaiah, 2002).

According to Semiun (2006), there are four aspects that affect anxiety in a person:

Mood, aspects of mood in anxiety disorders are tense, panic and fear. People who experience anxiety sense the existence of punishment or disaster that would threaten them from unknown sources. Other aspects of mood are depression and irritability.

Cognitive, cognitive aspects of anxiety disorders show worries and concerns regarding the anticipation of disaster by individuals.

Somatic, something which indicates body's reaction, such as sweating, fast heart beating, dry mouth, weakness, and nausea.

Motoric, it is a high stimulation of cognitive and somatic aspects to protect a person from feelings of insecurity, as manifested in being restless, nervous, and shaking.

According to Trismiati (2004), there are two factors that can affect a person's anxiety:

Internal, that is having no confidence in one's abilities. Freud suggested that the weak ego would lead to a threat that triggers anxiety.

External, such as inconvenience in one's abilities, threat, conflict, and fear.

There are two preparations that must be met by the pilgrims before their departure, as explained by Gayo (2002) :

Physical preparation, covering general check-up to check overall physical conditions; exercise to maintain cardiac health and muscle flexibility is needed when performing thawaf, sa'i and throw jumrah, also practice walking under the scorching sun, and personal consultation.

Spiritual preparation, that is being sincere and broadminded to accept whatever will happen in the holy land to escape from worldly affairs. Another spiritual preparation is the attitude of patience and mutual helpfulness, which is very necessary when performing the pilgrimage.

At the time of Hajj, pilgrims come from various countries with various habits and personalities, that may do unfamiliar behavior, like shoving and jostling, lining in a long queue to enter mosques, waiting for vehicles and grabbing queues.

\section{METHOD}

This research subjects are 2 couples of pilgrims, who fulfill these criteria: performing Hajj when they are over 60 years old, had never performed the Hajj or Umrah before or the last Hajj was done at least 3 years ago, using regular pilgrimage program, performing Hajj as couples and unaccompanied by other members of family, are physically healthy and had no history of serious illnesses (stroke, heart disease, asthma) or allergies (allergic to weather, food, or dust). With the defined criteria, the subjects were chosen by purposive sampling method. The method of data collection is qualitative method, with interviews and closed questionnaires.

\section{RESULTS AND ANALYSIS}

All of subjects are experiencing diverse anxieties, originating from cognitive problems before conducting Hajj, such as fear of being trampled, inability to survive, and severe pain because of age. When a person is getting older, they tend to potentially experience health problems (Suyanta\&Ekowarni, 2012).

Table I. Result Conditions

\begin{tabular}{lllll}
\hline ASPECTS & S1 & S2 & S3 & S4 \\
\hline Cognitif & V & V & V & V \\
\hline Mood & V & V & V & V \\
\hline Somatic & V & V & V \\
\hline Motoric & \multicolumn{5}{c}{ V } \\
\hline \multicolumn{5}{l}{ Notes: $(\mathrm{V}):$ anxiety }
\end{tabular}

Fear of threat on the loss of self-integrity is one of the causes of elderly anxiety. Nurhayati (2012) explained that elderly have concerns over their health and wellbeing. Gayo (2002) explained that in the preparation of Hajj, patience is one of the main keys and the attitude to be prepared. Gayo mentioned that mutual help and patience are indispensable when conducting Hajj. During the process of Hajj, pilgrims from various countries with various habits and personalities could give rise to uncommon behaviors. Papalia, Olds, and Feldman (2009) explained that the elderly who are facing a less favorable situation tends to become more mature in thinking and making decisions, because they have enough life experience and is more prudent.

On mood aspects, subjects appeared to feel worry during Hajj. However, as they gained more experience, they became more focused predominantly on the pilgrimage, so that they could ignore unpleasant feelings. Feist \& Feist (2009) explained that humans have an organismic valuing process in the form of natural instinct that would lead one to achieve goals that are considered meaningful.

Somatic aspect analysis found that exhaustion and sleeplessness were experienced by the subjects 1,3 , and 4 because some places for performing Hajj must be 
reached on foot, there were limited spaces to rest, and the location was full of gravel. These findings are in agreement with Ramaiah (2002), that anxiety could appear alone or joined with other symptoms of emotional disorders due to environmental condition, depression, and physical causes.

Anxiety experienced by the subjects, such as fear of stampede, being crushed, concern about health, or even death was managed using two methods; adaptive coping (positive management) such as performing a lot of prayer, being grateful for what one has, and being more broad-minded and sincere. On the other side, maladaptive coping (negative management) was also carried out by a subject to reduce the experienced anxiety such as being grumpy and encouraging other pilgrims to complain (Nurhayati, 2012).

\section{CONCLUSION}

The whole subject of the study experienced anxiety during the procession of pilgrimage, especially when performing mabit in Muzdalifah, and throwing jumrah in Mina. Environmental conditions, such as crowds of worshipers, extreme hot weather, emotional state of irritability, and declining physical conditions had triggered the emergence of anxiety during pilgrimage. Being broad-minded, performing more prayer, and seeking forgiveness were the methods conducted by the subjects to overcome their experienced anxiety. In addition, high motivation to complete the procession of pilgrimage and sincere intentions to God reduced the anxiety as experienced by the subjects.

\section{SUGGESTIONS}

Interested researchers are expected to study elderly pilgrims who perform the Hajj alone without being accompanied by spouse or family. Researchers can also examine anxiety of the elderly before performing Hajj.

\section{REFERENCES}

Djumhana, H. (2001). Integrasi Psikologi dengan Islam. Yogyakarta: Yayasan Insan Kamil.

Feist, J. \& Feist, G.J., (2009). Teori Kepribadian. Jakarta: Salemba Humanika.

Gayo, H. I. (2002). Buku Pintar Haji dan Umrah. Jakarta: Pustaka Warga Negara.

Juwita, S. K. (2013, Oktober 27). Pentingnya Support in Group. Retrieved Desember 25, 2013, from http://puskeshaji.depkes.go.id/:http://puskeshaj i.depkes.go.id/webs/berita-230-pentingnyasupport-in-group.html

Nurhayati, S. R. (2012). Dukungan Sosial dan Strategi Coping Para Lansia. Jurnal Penelitian Humaniora, 17(01), 43-60.
Papalia, D. E., Olds, S. W., \& Feldman, R. D. (2009). Human Development PerkembanganManusia. Jakarta: SalembaHumanika.

Ramaiah, S. (2002). Kecemasan. Jakarta: Pustaka Populer Obor.

Santrock, J. W. (2012). Perkembangan Masa Hidup. Jakarta: Penerbit Erlangga.

Semiun, Y. (2006). Kesehatan Mental 2. Yogyakarta: Kanisius.

Suardana, A. P., \& Simarata, N. (2013). Hubungan Antara Motivasi Belajar dan Kecemasan pada Siswa Kelas VI Sekolah Dasar di Denpasar Menjelang Ujian Nasional. Jurnal Psikologi Udayana, 203-212.

Suardiman, S. P. (2011). Psikologi Lanjut Usia. Jogjakarta: Gajah Mada University Press.

Suyanta, \& Ekowarni, E. (2012). Pengalaman Emosi dan Mekanisme Koping Lansia yang Mengalami Penyakit Kronis. Jurnal Psikologi, 39(2), 208221.

Tausikal, M. A. (2013, September 19). Syarat Mampu dalam Haji. Retrieved Desember 12, 2014, from muslim.or.id: http://muslim.or.id/fiqhdan-muamalah/syarat-mampu-dalam-haji.html

Trismiati. (2004). Perbedaan Tingkat Kecemasan Antara Pria dan Wanita Akseptor Kontrasepsi Mantap Di RSUP Dr. Sardjito Yogyakarta. Journal Psyche, 01(01), ---. 